\title{
Should Iodine be Supported in Pregnancy? A Hospital Based Study
}

\section{Gebelikte İyot Desteği Gerekli Midir? Hastane Temelli Bir Çalışma}

\author{
Hulya Parildar*I, Guldeniz Aksan Desteli ${ }^{2}$, Tevfik Berk Bildact ${ }^{2}$, Ozlem Cigerli $^{1}$
}

\begin{abstract}
Objective: Iodine deficiency causes adverse effects in pregnant women and neurological-cognitive disorders in their babies. Our aim was to define the status of iodine deficiency among pregnant women, who attended our hospital outpatient polyclinics. Materials and Methods: This cross-sectional and descriptive study was performed in 2014 with 94 pregnant women. Iodine levels in spot urine and serum thyroid hormones have been analyzed. The iodine levels of spot urine less than $150 \mu \mathrm{g} / \mathrm{L}$ were accepted as iodine deficiency. Results: The mean age was $30.6 \pm 3.92$ years, mean gestational age was $18.9 \pm 9.64$ weeks. Mean urinary iodine concentrations (UIC) were $160.32 \pm 5.88 \mu \mathrm{g} / \mathrm{L}$ and the ratio of pregnant women whose UIC less than $150 \mu \mathrm{g} / \mathrm{L}$ was $33 \%(\mathrm{n}=31)$ and the percentage of the women, who declared iodised salt use was $90.2 \%$. Conclusion: In this study, in one-third of pregnant women the urine iodine concentrations were inadequate despite the high rate of iodised salt intake. Nevertheless, most prenatal vitamins and salts do not include adequate iodine, iodine monitoring and supplementation may be recommended before and during pregnancy.
\end{abstract}

Key words: Pregnancy, iodine deficiency

\section{ÖZET}

Giriş: İyot eksikliği, gebelerde olumsuz etkilere, bebeklerinde ise nörokognitif bozukluklara neden olmaktadır. Çalışmamızda hastanemiz polikliniklerine başvuran gebe kadınlarda iyot eksikliğinin araştırılması amaçlanmıştır. Yöntem: $\mathrm{Bu}$ kesitsel ve tanımlayıcı çalışmaya, 2014 yılında takip edilen, 94 gebe dahil edilmiştir. Çalışmaya alınan gebelerin, anlık (spot) idrarda iyot düzeyleri ve tiroid fonksiyon testleri analiz edilmiştir. Spot idrarda iyot düzeyi $<150 \mu \mathrm{g} / \mathrm{L}$ ise iyot eksikliği

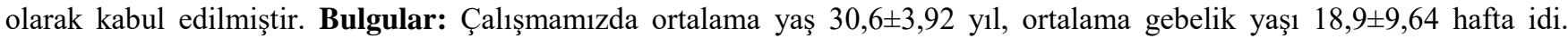
Ortalama idrar iyot atılımı $160,32 \pm 5,88 \mu \mathrm{g} / \mathrm{L}$ olarak saptanmış olup, iyot eksikliği olanların oranı \%33 olarak bulunmuştur. İyot katkılı tuz kullandığını belirten gebelerin oranı \%90,2 idi. Sonuç: İyot katkılı tuz kullanımının yüksek oranda olmasına karşın, gebelerin üçte birinde idrar iyot düzeyleri yetersiz düzeyde saptanmıştır. Bulgularımız, gebelerde iyot eksikliği prevalansının önemli bir düzeyde olduğunu vurgulamaktadır. Ülkemizde prenatal vitaminlerin çoğunda ve tuzlarda yeterli iyot bulunmamaktadır, bu nedenle gebelik sırasında veya öncesinde iyot durumunun değerlendirilmesi ve desteklenmesi önerilebilir.

Anahtar kelimeler: Gebelik, iyot eksikliği

\footnotetext{
Received / Geliş tarihi: 18.04.2017, Accepted / Kabul tarihi: 25.11.2017

${ }^{1}$ Baskent University, Department of Family Medicine, Istanbul Hospital

${ }^{2}$ Baskent University, Department of Gynecology and Obstetrics, Istanbul Hospital

*Address for Correspondence / Yazışma Adresi: Hulya Parıldar, Baskent University, Department of Family Medicine, Istanbul Hospital Istanbul-

TURKEY, E-mail: hulyaparildar@gmail.com
}

Parildar H, Desteli GA, Bildac1 TB, Cigerli Ö. Should Iodine be Supported in Pregnancy? A Hospital Based Study. TJFMPC, 2018;12(1): 19-23. DOI: $10.21763 /$ tjfmpc.400112 


\section{INTRODUCTION}

Iodine, which is a trace element, is an essential component of the thyroid hormones (i.e. thyroxine T4 and triiodothyronine-T3, with iodine comprising $65 \%$ and $59 \%$ of their weights, respectively) ${ }^{1}$. Thyroid hormones regulate metabolic processes in most cells and are playing a determining role in the process of early growth and development of most organs, especially that of the brain. In humans most of the growth and development of the brain occurs during the fetal period and the first two to three years of postnatal life. Iodine can be obtained by consumption of foods, that naturally contain it (i.e. salt water fish, seaweed, egg yolk, soya milk, soy sauce, and vegetables grown in iodine sufficient soil) and iodized table salt ${ }^{1,2}$. Iodine deficiency is one of the main preventable cause of brain damage and impaired cognitive development in children. Severe iodine deficiency during pregnancy has been associated with miscarriages, stillbirth, preterm delivery, and congenital abnormalities. The spectrum of iodine deficiency disorders (IDD) includes mental retardation, hypothyroidism, goiter, and varying degrees of other growth and developmental abnormalities 2,3

Approximately $85-90 \%$ of the iodine consumed by the body is excreted by urine. The measurement of urinary iodine levels in a specific region is an important criterion, that reflects the iodine status in that region. Iodine deficiency in pregnancy is defined as median urinary iodine concentrations (UIC) less than $150 \mu \mathrm{g} / \mathrm{L}$ (Table 1). Spot UIC correlate well with 24-hour urine collections. A recent survey of all prescription and non-prescription (OTC) prenatal vitamins in USA showed, that only approximately $50 \%$ contained any iodine, Since the iodine in prenatal multivitamins was provided in the form of kelp, the amount of daily iodine was dramatically variable ${ }^{4}$. In Europe, only 15-30\% of pregnant women use vitamins containing iodine ${ }^{5}$. Therefore the risks of pregnant women and their children should be determined by population screenings, which should be more frequently done even in areas under salt iodisation program. World Health Organization (WHO) stated a broad consensus about the requirement of iodine during the period of pregnancy, lactation and childhood and had published new guidelines. WHO recommends that the daily iodine consuming amount should be 220 $\mu \mathrm{g}$ for pregnant and lactating women. Institute of Medicine (IOM) recommends an upper limit of $1.100 \mathrm{mcg}$ dietary iodine daily during pregnancy ${ }^{6}$. The benefits of preventing iodine deficiency far outweigh the risks of supplementation as long as supplementation is not excessive ${ }^{7}$. As for our country, it has been reported that some regions still suffered from iodine deficiency and there are no routine practice guidelines regarding this issue ${ }^{8-10}$.

In this study, we aimed to evaluate the iodine status and if necessary to determine the iodine requirement of pregnant women, who attended a university hospital in Istanbul.

\section{MATERIALS AND METHODS}

This was a cross-sectional, descriptive and hospitalbased study performed with 94 pregnant women, who attended Başkent University Istanbul Hospital outpatient obstetric clinics in March 2014. We excluded pregnant women with abnormal thyroid function tests, who were uncooperative with physician recommendations, having multiple pregnancies, and with the diagnosis of mental or physical function disorder or organ failure, because these conditions might intervene the study results. Socioeconomic status was similar among the participants of this study. All pregnant women were taking prenatal vitamins without iodine on their initial prenatal visits. Their spot urine samples were collected. The UIC, serum thyroid functions, and basal biochemical laboratory tests were analysed. The iodine status of pregnant women was evaluated on the basis of mean urinary iodine concentrations in spot urine according to WHO criteria. The UIC between $150-249 \mu \mathrm{g} / \mathrm{L}$ in pregnancy were accepted as optimal, levels less than $150 \mu \mathrm{g} / \mathrm{L}$ were described as iodine deficiency. The colorimetric urinary analysis was performed by spectrophotometry.

A questionnaire including items on consuming and preservation patterns of household salt was used. The questionnaire included three 'yes or no type' questions about patients' preference on buying iodine fortified salt or not, whether salt was used during the cooking process or afterwards and keeping salt in a dark place or not.

Statistical analysis was performed by using standard SPSS version 11.0. Data were presented as mean and standard deviation when normally distributed. One-way ANOVA followed by Tukey's test was used for between-group comparisons. Correlations were evaluated via Pearson correlations analysis. For non-normal distributions, data were presented as median (range), (standard deviation; SD) and percentage (\%) where appropriate.

Informed consent was obtained from each subject following a detailed explanation of the objectives and protocol of the study which was carried out in accordance with the ethical principles stated in the "Helsinki Declaration". This study was approved by Baskent University Institutional 
Review Board (No:KA09/356).

\section{RESULTS}

The mean age of subjects was $30.6 \pm 3.92$ years $(\min =21, \max =42)$, mean gestational age was $18.9 \pm 9.64$ weeks $(\min =4, \max =37)$. Mean UIC were $160.32 \pm 50.88 \mu \mathrm{g} / \mathrm{L}(\min =20.70, \max =260.19)$ in total. The percentage of the pregnant women whose mean urinary iodine levels less than 150 $\mu \mathrm{g} / \mathrm{L}$ was $\% 33$ ( $\mathrm{n}=31), 12.8 \%$ (n: 12$)$ of them had UIC less than $100 \mu \mathrm{g} / \mathrm{L}$ (Table II). UIC according to gestational age were shown in Table III. The percentage of the women, who declared the usage of iodised table salt was $90.2 \%$.

Mean serum TSH levels for first, second and third trimester were 1.98, 1.45 and 1,89 $(\mu \mathrm{IU} / \mathrm{mL})$, respectively. Serum free T3 (fT3) and free T4 (fT4) levels were 2.49/1.42, 3.20/1.03 (ng/dL) and 3.69/0.97 (ng/dL) for the first, second and third trimesters, respectively. No significant differences were observed (one-way ANOVA with Tukey's HSD posthoc analyses) between trimesters for urinary iodine concentrations and serum thyroid hormone (TSH, f T4, f T3) levels. There were no significant correlations between urinary iodine concentrations and gestational ages also no significant correlations were found between thyroid hormone levels and urinary iodine concentrations.

\section{DISCUSSION}

Women, who are pregnant or lactating have increased dietary iodine requirements. Severe iodine deficiency leads to adverse maternal and fetal consequences. Even mild-to moderate iodine deficiency in pregnancy has adverse effects on obstetric and neonatal outcomes. Qian $\mathrm{M}$ et al, reviewed the trials that compare intelligent quotient status of totally 12.291 children grown up in different regions with those in severely iodine deficient (ID) areas or children in ID areas born before and after the introduction of iodine supplementation ${ }^{11}$. Unfortunately iodine sufficient control groups were superior socially, economically, and educationally with the study groups. Recent data on the neonatal neurocognitive impacts of early iodine supplementation suggests that adequate iodine intake should be incorporated as part of preconception planning or be started as soon as the patient is aware of her pregnancy. Despite efforts have been made such as mandatory salt iodization, Turkey is estimated to be among over 50 mild iodine deficient areas in the world $3,12,13$. Considering these criteria, most of the women in the world are far behind the goals.

In this study, $33 \%$ of pregnant women, who attended to our obstetric outpatient clinics had iodine deficiency (UIC less than $150 \mu \mathrm{g} / \mathrm{L}$ ); with $12.8 \%$ of them below $100 \mu \mathrm{g} / \mathrm{L}$ despite high iodinefortificated table salt use.

Fortificated table salt use is another important issue. If salt is added during the time of cooking, heat could be a factor decreasing the bioavailability of iodine. Although our result is much better than the findings of previous Turkish studies, it is known that this ratio is even more higher in some of the regions. A recent study showed that moderate to severe iodine deficiency still exists in $27.8 \%$ of general Turkish population (not only in pregnant women), which is much better compared to 1997 and 2002 surveys (58\%, 38.9\%, respectively) ${ }^{8}$. The percentage of pregnant women with UIC below $100 \mu \mathrm{g} / 1$ was 83.3 in a study from the eastern region ${ }^{8}$. Kut et al found that almost half of the subjects' UIC were less than the median reference limits of $150 \mu \mathrm{g} / 1$ and the rate for iodized salt use among the pregnant women was 95\%, which was higher than the percentage found in this study $(90.2 \%)$ in Ankara ${ }^{10}$. The proportion of iodized salt use was $80.2 \%$ in another study in the same city in Turkey and UIC was below $150 \mu \mathrm{g} / \mathrm{l}$ in $72 \cdot 8 \%$ of pregnant women ${ }^{14}$.

There has been a progress in our country about struggling with iodine deficiency. However, there is still deficiency and it differs a lot with gestational age, gender and regions. Most of the prenatal vitamins available in our country or in other countries do not contain adequate iodine ${ }^{3,4}$. This is also the case for prenatal vitamins on the market, which are have no uniform content in their iodine content. The women who had low urinary iodine levels, we recommended routine use of iodised salt and $250 \mu \mathrm{g} /$ daily iodine intake with iodine containing supplements.

Because the halogen iodide slowly oxidises to metal carbonate and elemental iodine, by exposure to excess oxygen and carbon dioxide and evaporates, iodised table salt may lose its iodine content by exposure to excess air over time and by cooking ${ }^{15}$. This is a very important issue, since little is known about these patterns and the loss of iodine between production and consumption are usually ignored. Since non-iodized salts are still available on the market or iodine content of the salts are not written on food packaging labels, it is not possible to estimate the real consumption. Therefore iodine intake among the population may not be uniform. Poor education or awareness about the medical necessity of using iodized salt during pregnancy is another reason.

The limited size of the study group, lack of thyroid volume screening, and missing of the correlation of maternal iodine status with thyroid volume were the several limitations of our study. 
However the urinary iodine concentration indicates current iodine intake, while thyroid size and serum thyroglobulin concentrations reflect iodine status over a couple of months or even years. Only serum thyroid function tests and the medical history of thyroid disease with or without drug therapy, which affect the functions of the thyroid gland was retrieved during this study.

In conclusion, recent studies on the neonatal neurocognitive impact of early iodine supplementation and increased iodine requirements in pregnant and lactating women; adequate iodine intake should be planned pre-conceptionally or started as early as possible during pregnancy. Nevertheless, the content and preservation of iodine in table salt and OTC drugs are very important; prenatal care measures by the health professionals may be the world's simplest and most cost-effective ways available to improve this major public health problem. Common protocols might be developed in order to evaluate the actual iodine deficiency and to promote the consumer awareness.

\section{Declaration of Interest:}

No author has any potential conflict of interest.
Table 1. WHO (2007) criteria for assessing iodine nutrition, based on the median or range, in urinary iodine concentrations of pregnant women

\begin{tabular}{|l|l|l|}
\hline \multirow{1}{*}{} & $\begin{array}{l}\text { Median } \\
\text { urinary iodine } \\
\text { concentration } \\
(\mu \mathrm{g} / \mathrm{L})\end{array}$ & $\begin{array}{l}\text { Iodine } \\
\text { intake }\end{array}$ \\
\hline \multirow{4}{*}{$\begin{array}{l}\text { Pregnant } \\
\text { women }\end{array}$} & $250-499$ & Insufficient \\
\cline { 2 - 3 } & $150-249$ & Adequate \\
\cline { 2 - 3 } & $\geq 500$ & $\begin{array}{l}\text { Above } \\
\text { requirements }\end{array}$ \\
\cline { 2 - 3 } & & Excessive \\
\hline
\end{tabular}

Table 2. Iodine concentrations of pregnant women in spot urine ( $\mu \mathrm{g} / \mathrm{L})$ (WHO 2007)

\begin{tabular}{|c|c|c|}
\hline $\begin{array}{c}\text { Urinary iodine } \\
\text { concentrations }\end{array}$ & \multicolumn{1}{c|}{$\mathrm{n}$} \\
\hline$<100$ & 12 & 12.8 \\
\hline $100-150$ & 19 & 20.2 \\
\hline$>150$ & 63 & 67 \\
\hline
\end{tabular}

Table 3. Urinary iodine concentrations according to gestational age (WHO 2007)

\begin{tabular}{|c|c|c|c|c|}
\hline & & Age (years) & $\begin{array}{l}\text { Gestational } \\
\text { age (weeks) }\end{array}$ & $\begin{array}{l}\text { Urinary Iodine } \\
\text { Concentrations }(\mu \mathrm{g} / \mathrm{L})\end{array}$ \\
\hline \multirow{3}{*}{$\begin{array}{l}\text { 1st Trimester } \\
(n=36)\end{array}$} & Mean & 30.3 & 8.3 & 160.3 \\
\hline & SD & 5.1 & 2.5 & 50.8 \\
\hline & Min-max & $21-42$ & 4-12 & $20.7-260.2$ \\
\hline \multirow{3}{*}{$\begin{array}{l}\text { 2nd Trimester } \\
(\mathrm{n}=21)\end{array}$} & Mean & 30.8 & 18.7 & 170.0 \\
\hline & SD & 3.7 & 3.2 & 60.2 \\
\hline & Min-max & $23-37$ & $13-24$ & $20.9-240.3$ \\
\hline \multirow{3}{*}{$\begin{array}{l}\text { 3rd Trimester } \\
(\mathrm{n}=37)\end{array}$} & Mean & 30.8 & 29.3 & 150.8 \\
\hline & SD & SD & 4.1 & 4.0 \\
\hline & Min-max & $21-42$ & $24.5-37$ & $30.20-240.5$ \\
\hline \multirow[t]{3}{*}{ Total $(n=94)$} & Mean & 30.6 & 18.9 & 160.3 \\
\hline & $\mathrm{SD}$ & 4.4 & 9.9 & 50.6 \\
\hline & Min-max & $21-42$ & $4-37$ & $20.7-260.2$ \\
\hline
\end{tabular}




\section{REFERENCES}

1. Andersson M, Karumbunathan V, Zimmermann MB. Global iodine status in 2011 and trends over the past decade. Journal of Nutrition 2012;142: 744-750

2. Zimmermann MB. Iodine deficiency in pregnancy and the effects of maternal iodine supplementation on the offspring: A Review. Am J Clin Nutr 2009; 89(2):668-672.

3. Zimmermann MB, Delange F. Iodine supplementation of pregnant women in Europe: A review and recommendations. Eur $\mathrm{J}$ Clin Nutr 2004; 58(7): 979-984.

4. Yarrington C, Pearce EN. Iodine and Pregnancy. Journal of Thyroid Research. 2011;2011:934104.

5. Vitti P, Rago T, Aghini-Lombardi F, Pinchera A. Iodine deficiency disorders in Europe. Public Health Nutr.2001;4(2B):529-535.

6. Russel R, Beard J, Cousins R, Dunn J, Ferland G, Hambidge KM et al. Panel on micronutrients. Dietary reference intakes for vitamin A, vitamin $\mathrm{K}$, arsenic, boron, chromium, copper, iodine, iron, manganese, molybdenum, nickel, silicon, vanadium, and zinc, National Academy Press, Washington, DC, USA. 2001:275-278

7. Braverman LE. Adequate iodine intake-the good far outweighs the bad. European Journal of Endocrinology 1998;139(1):14-15.

8. Egri M, Ercan C, Karaoglu L. Iodine deficiency in pregnant women in eastern Turkey (Malatya Province): 7 years after the introduction of mandatory table salt iodization. Public Health Nutr 2009;12(6) 849-52.

9. Erdoğan MF, Ağbaht K, Altunsu T, Ozbas S, Yucesan F, Tezel B. et al. Current iodine status in Turkey. $\mathrm{J}$ Endocrinol Invest 2009;32(7):617-622.

10. Kut A, Gursoy A, Senbayram S, Nilüfer B, Isıl IB, Akgün $\mathrm{S}$. Iodine intake is still inadequate among pregnant women eight years after mandatory iodination of salt in Turkey. J Endocrinol Invest 2010;33(7):461464.

11. Qian M, Wang D, Watkins WE, Gebski V, Yan YQ, et al. The effects of iodine on intelligence in children: a meta-analysis of studies conducted in China. Asia Pac J Clin Nutr. 2005;14(1):32.

12. Erdoğan MF. The iodine status of Turkey: Where were we? Where are we now? Review. Türkiye Klinikleri J Endocrin Special Topics 2008; 1 (3):8-13.

13. Pearce EN, Andersson M, Zimmermann MB. Global iodine nutrition: Where do we stand in 2013? Thyroid. 2013;23(5):523-528.

14. Oguz Kutlu A, Kara C. Iodine deficiency in pregnant women in the apparently, iodinesufficient capital city of Turkey. Clin Endocrinol (Oxf) 2012;77(4):615-620.

15. Katarzyna W, Krystyna SB. Effect of storage conditions on potassium iodide stability in iodized table salt and collagen preparations. International Journal of Food Science \& Technology 2007;43(5):895 -899. 